\title{
제 8차 캄보디아 원조공여국 회의
}

\section{I. 보고 요지}

- 향후 5년간 전략적 국가개발계획(NSDP 2006-2010) 이행을 위한 개발협력의 효율성 증대를 주제로 3.2(목) 3.3(금)간 캄보디아에 서 세계은행과 캄보디아 정부 공동주관으로 제 8차 원조공여국 회의가 개최되었음.

- 금번 회의에서는 원조공여국과 주재국 정부가 공동개발한 NSDP 2006 2010의 이행 전략인 공공투자프로그램 (Public Investment Program) 및 동 상황 점검을 위한 공동 모니터 링 지표(Joint Monitoring Indicator 2006)가 채택됨.

- 아울러 금번 회의에서는 총 601 백만 불의 원조 공약이 이루어졌는바, 지난 2004.12월 제7차 회의 시 공약된 총 501 백만 불을 훨씬 초과하는 금액임.

- 우리는 향후 2 3년에 걸쳐 시행중인 사업을 포함, 총 2 개 사업에 차관을 지원할 예정이며
(총 39.5백만 불, 연평균 15 백만 불 수준), 무 상원조 7 백만 불, NGO 3 백만 불 등 총 25 백 만 불의 지원 의사를 밝힘.

\section{II. 회의 결과}

- 표제회의가 3.2(목) 3.3(금)간 세계은행 및 캄 보디아 정부 공동주관으로 Hun Sen 총리, Sok An 부총리 겸 관방부장관, Keat Chhon 재경부장관 등 관련 부처 장-차관을 포함한 캄보디아 정부 대표단과, 총 12 개 원조 공여국 (한국, 미국, 일본, 프랑스, 영국, 독일, 캐나다, 호주 등), 5 개 국제기구(세계은행, $\mathrm{ADB}, \mathrm{IMF}$, $\mathrm{UNDP}, \mathrm{EU}), 6$ 개 옵저버국가(러시아, 폴란드 등), NGO 및 민간부문 대표 등이 참가한 가운 데 캄보디아에서 개최 되었는 바, 주요 내용을 아래 보고함. 


\section{1. 개회식 연설요지}

\section{가. Hun Sen 총리(기조연설)}

- 2004.12월 제7차 원조공여국회의 개최 이후 달성한 성과 및 향후 추진할 정책 목표를 소개 하고, 동 정책목표의 구체적 실천이 중요함을 역설함.

- 특히 캄보디아의 지속적 성장과 개혁을 위해 정치적 안정과 통합을 통한 민주주의 발전이 중요함을 강조함.

- 한편 동 총리는 현행 원조 매커니즘을 재평가, 원조 효율성 증대를 위해 18 개TWG(Technical Working Group)와 고위급 GDCC(Government - Donor Coordinaton Committee)를 설립 · 운영하고 있다고 하고, 기존 원조 공여국 (CG) 회의를 GDCC로 대체하는 등 메커니즘 개선이 필요하다고 언급함.

나. Ian Porter 세계은행 대표는 지난 제7차 회의 이후 각 의제별 진전사항과 당면과제를 소개하 며, 지속적 성장을 위해 공여국들이 캄보디아 정부의 정책에 맞춰 함께 노력할 것을 촉구함.

다. Keat Chhon 재경부장관은 지난 10 년간 캄보 디아의 경제성장 및 개혁 성과를 소개하며, 빈 곤퇴치 및 성장을 위한 부패근절, 부채 탕감의 중요성을 역설함. 특히 $\mathrm{IMF}$ 와 중국정부의 부 채탕감 조치에 사의를 표명하고, 각 분야별 주 재국 정부의 개선 방향을 폭넓게 제시함.

\section{2. 의제별 토의사항}

\section{가. 의제 $1:$ 최근 경제사회 개발성과}

- 캄보디아 정부측은 지난 10 년간의 경제성장 및 재정안정, 금융시장 발전 및 빈곤퇴치 등 전반적인 경제사회 개발 성과 및 향후 계획을 설명함.

a 이에 대해 IMF 대표는 캄보디아의 고도 경제성 장에 대한 평가와 함께 긍정적 전망을 제시하 면서 공여국 및 캄보디아 정부가 향후 지속적 으로 공조해 나갈 것을 촉구하고, 부채 탕감으 로 인한 추가재원의 효율적인 사용 및 농업생 산성 강화, 농촌개발을 통한 빈곤퇴치 및 사회 개발 투자 등을 촉구함.

※ MF는 캄보디아에 대해 1993년 이전 부채 8,200 만 불을 탕감

\section{나. 의제 2 : 국가전략개발계획 및 공공투자프로}

\section{그램}

a 캄보디아측은 사각전략의 구체 실행과 캄보디 아 새천년개발목표(CMDG) 달성을 위한 우선 순위 목표와 전략이 제시된 전략적 국가개발계 획(NSDP 2006 2010) 및 동 전략지원 3개년 계획인 공공투자프로그램(PIP 2006 2008)을 소개하며, 원조 공여국들이 동 NSDP 및 PIP에 맞춰 원조를 추진해 줄 것을 촉구함.

- 이에 대해, $\mathrm{ADB}$ 측은 파리선언에 따라 원조 공 여국들이 NSDP에 맞추어 지원해 나갈 예정임 을 밝히고, 캄보디아 정부 측에 자체재원 확보 
에 더욱 노력하고 세계은행의 빈곤평가보고서 에 따라 $\mathrm{NSDP}$ 의 세부계획, 동 계획 이행 모니 터링 및 평가 메커니즘 수립을 촉구함.

\section{다. 의제 $3: 2005$ 년 공동모니터링지표 평가 및 2006년 지표 채택}

- 캄보디아 정부 측은 2005년 공동모니터링지표 평가 결과가 반영된 총 12 개 분야에 걸친 새로 운 공동모니터링지표(JMIs)를 제시함 (상세 별 첨 3 참조).

- 이에 대해 미국 측은 지난번 회의에 이어 캄보 디아의 부패를 "disease, plague, cancer" 에 비유하며 그 심각성을 지적하고, 국제수준에 맞는 강력한 반부패법 제정 등 보다 과감한 조 치를 취할 것을 촉구함.

a 프랑스 측은 사법제도 개선과 관련, 2004년 12 월 공동모니터링지표로 설정되었던 8개 기초법 안의 조속 입법을 요구함.

- 덴마크 측은 행정 분야 개선 관련, 지표 달성을 위해 관련부처의 공조 및 정책결정권자의 결단 의 중요성을 강조함.

- 세계은행은 공공재정개혁이 지속가능한 개발 의 초석임을 강조하고, 투명하고 효율적인 재 정집행의 중요성을 역설함.

- 독일 측은 천연자원 관리 및 농업분야 개혁과 관련, 토지 및 광산 소유권 허가에 대한 보다 투 명한 정보공개를 촉구하며, 소유권 집중을 통 한 빈부격차 확대 가능성을 우려함. 또한, 농촌 빈민들의 토지 확보를 위한 불법벌목이 산림훼
손 및 지력 저하로 이루어지지 않도록 산림 및 농업을 포괄하는 정책 수립 및 집행을 요구함.

- 한편 일본 측은 농업개발과 수자원 관리를 연 계하는 포괄적 정책 수립의 필요성을 제시함.

\section{라. 의제 $4:$ 원조효율성 증대}

- 캄보디아 정부 측은 파리선언 및 로마선언에 따라 원조효율성 증대를 위해 달성한 성과를 아래와 같이 발표하며, 향후 공여국측 또한 원 조 수행 시 캄보디아의 주인의식을 존중해 줄 것을 촉구함.

- 원조 조화와 일치를 위한 행동계획 수립 및 추진

- 개발협력 관리를 위한 전략적 틀 채택

- 캄보디아개발위원회 웹사이트를 통한 관련 정보 공개

- 이에 대해 영국정부는 캄보디아 정부가 원조효 율성 증대를 위해 취한 조치를 지지하며, 향후 기존의 공여국-캄보디아 정부간 조정 매커니즘 (Consultative Group Meeting, Government -Donor Cooperation Committee, Technical Working Group)을 강화하는 한편, SWAp (Sector Wide Approach)을 추진할 것을 제 안함.

\section{3. 우리측 수석대표 발언 요지}

캄보디아의 지속가능한 경제발전을 위해 향후에 도 국제사회의 지속적인 지원이 필요하며, 개발 협력 파트너들이 앞서 지적한 바 있는 우려와 제 
안에 동감하며, 주인의식 제고 및 원조효율성 증 대를 위해 캄보디아측이 추진하는 NSDP/PIP 이 니셔티브 및 노력이 소기의 성과를 달성할 수 있 기를 희망한다는 입장을 표명함

- (원조 공약과 관련) 우리 정부는 현재 시행중인 국도 3 번 개보수 사업에 대한 계속적인 차관지 원과 함께, $\mathrm{KOICA}$ 의 무상협력사업으로 실시한 타당성조사 결과를 바탕으로 크랑폰리강 유역 다목적 수자원 개발사업 추진을 위해 향후 $2 \sim 3$ 년에 걸쳐 신규차관을 지원할 예정임을 밝힘.

- 아울러 $\mathrm{KOICA}$ 를 통한 국립소아병원 현대화, 시엠립 우회도로 건설, 수자원개발 마스터플랜 수립 등 각종 무상협력 추진을 위해 2006년도 에 약 7백만 불을 지원할 계획이며, 민간차원의 각종 교류와 협력사업에 약 300만 불의 별도지 원이 이루어질 것으로 기대된다고 밝힘.

※ 회의 종료 후 캄보디아 실무자의 2006년도 지원 예정액 제시 요청으로 아래 산출근거에 따라 총 25백만 불 규모로 제시

- (국도 3번 1,200만 불/2년) + (수자원개발 2,700 백만 불/3년) + (KOICA 무상협력 7백 만) + (NGO 3 백만 불)

$=$ 총 2,500 만 불

\section{2006 년도 각국 원조 공약 현황}

가. 각국의 원조 공약에 앞서 Keat Chhon 재경부 장관은 PIP 2006 2008 추진에는 NSDP 2006 2010 전체예산 규모의 약 56.5\%인 총 1,975 백만 불이 필요하며 (2006년 600백만
불, 2007년 650백만 불, 2008년 725백만 불), 캄보디아 정부가자체적으로 확보할 수 있는 예산 초과분을 지원해 줄 것을 요청함.

- 지원요청액 : 2006년 513백만불,

2007년 633백만불,

2008년 578백만불

나. 금번 원조 공여국 회의에서는 총 601 백만 불의 원조공약이 이루어졌으며, 이는 2004년 제7차 회의 당시 공약된 504 백만 불에 비해 97 백만 불이 증가된 금액으로, 캄보디아 측이 지원 요 청한 513 백만 불을 56 백만 불 초과하는 규모임.

다. 금번 회의에서 주요 국가 및 국제기구들이 공 약한 원조 금액은 아래와 같음(캄보디아 정부 측에서 2006년 지원 공약 금액으로 임의 산술 집계한 수치)

- 주요원조공여국

- 일 본: 총 115 백만 불

- 미 국: 총 61 백만 불

- 프랑스 : 총 39백만 불

- 호 주: 총 32 백만 불

- 스웨덴 : 총 22 백만 불

- 덴마크 : 총 14 백만 불

- 캐나다 : 총 10 백만 불

- 국제기구

- EU : 총 164백만 불(무상)

- UN : 총 58백만 불

- WB : 총 53 백만 불 


\section{III. 관찰 및 평가}

1. 금번 회의에서는 주재국 정부의 5 개년 $\mathrm{NSDP}$ 2006 2010 및 공공투자프로그램 (PIP 2006 2008)이 발표되었으며, 동 NSDP 및 $\mathrm{PIP}$ 이행여부를 점검하기 위해 원조공여국과 캄보디아 정부가 공동으로 개발한 2006년도 공 동모니터링 지표 (JMIs)가 확정됨.

- 대부분의 원조 공여국들은 캄보디아가 달성한 경제성장 및 개혁 성과를 인정하면서도, 부패 퇴치, 천연자원 관리 및 농업분야, 공공재정개 혁 및 사법제도 개혁문제에서 보다 강도 높은 개혁이 필요하다는 점을 강조함.

- 특히 미국은 향후 캄보디아 정부의 실질적 개 혁추진 성과와 지원 규모를 연계하여 실제 지 원 규모를 조정하겠다는 입장을 표명함.

- 2005년도에 총 63백만 불(USAID를 통한 지원액 57 백만 불 포함) 지원

2. 한편 캄보디아 정부측은 그간 캄보디아에서 개최 되어온 그간 3차례의 원조공여국(Consultative Group ; CG) 회의가 원조 효율성 증대를 위한 조정역할에 비효율적이라고 판단, 고위급 정 부-공여국간 조정위원회(GDCC)로 대체하는 메커니즘 개선을 선호하고 있음을 밝힘.

- 차기 원조공여국회의는 2007년 6월 당지에 서 개최 예정

3. 또한 캄보디아측은 2009년 생산을 목표로 추
진 중인 남서부 해안 유전개발 (미국 Shevron 이 주도), 중북부 광물자원 개발(중국이 주도) 등 민간투자유치, 베트남, 태국, 말레이시아 등 ASEAN 회원국의 신규차관 제공에 의한 철도 및 도로 건설 지원 용의 표명 등에 고무되어 과 거 유럽(EU) 미국 눈치를 보던 입장에서 탈피, 독자적인 행보를 강화하고 있는 것으로 감지되 었음.

4. 대부분의 원조공여국들은 파리선언 등에 입각 하여 캄보디아 개발전략 수립 및 이행과정 참 여를 통해 각 분야별, 주제별로 특화된 원조를 수행하고 있는 바, 향후 우리도 주재국 원조 매 커니즘에 적극 참여하여 선택과 집중의 원칙에 따라 효율성 있는 원조를 수행하는 것이 필요 할 것으로 판단됨.

\section{IV. 특이사항}

1. 일본측은 당지 주재 대사를 수석대표로 JAICA 직원을 포함 총 6 7명이 참석하였으며, Pledge Session에서 2005년도 실제 지원실적이 당초 공약 보다 훨씬 많다는 점을 부각한 반면 2006 년도 지원액수에 대해서는 구체적 언급없이 예 년 수준이 될 것이라고만 밝힘.

- 또한 캄보디아 정부측이 기술원조를 점차 줄여 나가야 한다는 방침을 발표하자, 일본측은 특 정기관(CDC를 의미)의 편견이 아닌지 문의하 
고 현재 일본은 중장기적 안목에서 매년 약 50 60명의 전문가 파견을 통해 기술원조를 제 공하고 있으므로 향후 일본의 대캄보디아 지원 이 줄어들 것이라고 밝히는 등 다소 불편한 심 기를 드러냄.

2. 특히 $\mathrm{EU}$ 국가 대사들은 회의가 진행되고 있 는 시간에 회의장을 떠나 복도에서 의견을 교 환하는 모습을 보인 바, 캄보디아 정부측이 아 직도 과거의 구태의연한 행태에서 수원(受援) 자세에서 벗어나지 못했다고 하면서, 특히 각 종 부정부패 관련 공무원들에 대한 엄중단속 (인사조치 포함)이 가장 시급한 과제라는 입장 을 표명함.
3. 캄보디아 주재 북한대사도 첫날 상기 회의에 참석하였으나, 사전 참석통보를 하지 않아 일 반 참가자와 함께 뒷자리에 착석하였으며, 추 후 북한 측의 요청에 따라 회의 이틀째부터 우 리 대표단 좌석 옆에 국가 명패와 함께 자리를 준비하였으나 참석하지는 않았음.

4. 예년과 마찬가지로 중국은 상기 회의에 참석하 지 않았으며, 싱가폴(옵저버)을 제외한 여타 $\mathrm{ASEAN}$ 회원국들도 참석하지 않았음.

[자료: 주캄보디아 대사관] 